\title{
性役割態度研究の展望
}

\author{
早稲田大学 東清和 \\ 慶応義塾大学 鈴 木 淳 子
}

\section{Review of research on sex role attitudes}

Kiyokazu Azuma (Department of Educational Psychology, School of Education, Waseda University, Shinjuku-ku, Tokyo 169) and Atsuko Suzuki (Department of Sociology, Faculty of Letters, Keio University, Minato-ku, Tokyo 108)

There are many indices that roles of men and women have changed during the last two to three decades. This paper reviews psychological and sociological literature, and points out the following: (a) the shift of sex role attitudes, (b) their important predictors, and (c) some of cross-cultural comparisons. Sex role attitude is defined here as a learned tendency, which consistently responds favorably or unfavorably to certain sex roles. Since the 1970s, many panel surveys and longitudinal surveys, both in Japan and in USA, show that sex role attitudes have shifted toward an egalitarian direction in many fields. Cross-cultural surveys in many countries revealed that the most important predictors of sex role attitudes are, sex, education, vocation, and age. Highly educated young women with a professional/managerial job show probably the most egalitarian sex role attitude. However, cross-cultural studies indicate that Japanese women have more traditional sex role attitudes than those in other countries.

Key words: sex role attitudes, sex differences, shift towards egalitarian direction, cross-cultural research.

はじめに，日本を含む先進工業諸国の女性の間では， 過去 20-30 年の閒に未婚女性の増加・高学歴化・既婚 女性の就労の増加・就労分野の拡大が顕著になった. 女 性労働者の増加は女性の社会における地位の変化を示す 最も明白な指標 (Gerson, 1985, p. 1) だが，法的・政治 的な場面でも女性の地位は変化しつつある。このような 女性の人工統計学的変化を背景に, 男女の役割の変化, すなわち，性役割の再構築が起こっている.

本論文の目的は, 性役割の変化に伴って, 人々の性役 割態度が (1) どのように変化し；(2) どのような変数と 強く関連しているか；(3) どのような比較文化研究があ るのかを心理学および社会学の文献研究を通して明らか にすることである. なお，ここでは，数多い文献の中か ら主に次のような条件を満たす研究を選んだ：(a) 大学 生以上の成人を対象にした研究；(b) 性役割態度そのも のを目的にした研究；(c) 心理学的研究においては，信 頼性・妥当性の検討がおこなわれたところの性役割態度 測定尺度を使用した研究。

\section{1 心理学における性役割研究}

心理学における性役割の研究は 19 世紀末頃の性差研 究に始まり，パーソナリティ特性・行動・態度・興味・ 達成・能力に関する性差について実証的な研究が行われ
てきた. 研究者の関心は, 男女差の存在を前提にして, 性差が生物学的に規定されているのか，それとも文化に よるものかの原因究明に向けられていた.

しかし，アメリカにおける女性解放運動の影響を受け て, 1960 年代には既成の研究の批判的再検討が始まり, 1970 年代には性差および女性の性役割研究が飛躍的に 増加した. 性差, 性役割に関して次の 3 つ画期的な心 理学的研究結果が発表された：(a) 性役割の習得には社 会化が大きな役割を果たすこと（Money \& Ehrhardt, 1972); (b) 科学的に認められる性差は視覚 - 空間把握能 力・数学的能力・言語能力・攻撃性のみであり, 男女間 には共通点の方がはるかに多数存在すること (Maccoby \& Jacklin, 1974)；(c) 男性性と女性性の両方の特性を兼 补備えた心理的両性具有 (androgyny) が存在し, 両性 具有者恃社会的適応がよく, 心理的に安寧であること (e.g., Bem, 1974, 1976). これらの研究が, 性差や性によ る役割分業の正当性の根拠となる従来の見解を覆し, 1970 年代半ば頃からは男性の性役割も重要な研究分野 となり，性役割研究は新たな段階に入った。

1980 年代に入っても性差や性役割の研究は衰えず, 性役割に関する学際的研究が増加し, 比較文化研究も目 立つようになった。これは，幅広い分野において性役割 や性差の知識へのニーズや関心が高まってきたためと思 
われる。

\section{2 性役割態度研究}

性役割とは，それぞれの性にふさわしいと期待される パーソナリティ特性・行動特性・意識である (e.g., Andersen, 1988; 柏木, 1973; 間宮, 1979) と同時に, そ水 らを順守するようにと圧力をかける社会的規範 (e.g., 平 野・神田・小林・リドル，1980) でも亦る。 そこで，本 論文では，性役割を男女にそれぞれふさわしいとみなさ れる行動やパーソナリティに関する社会的期待・規範拧 よびそれらに基づく行動であると定義する.

心理学 (社会心理学を含む) に抬ける性役割研究には, 男性性 (masculinity), 女性性 (femininity), 两性具有 (androgyny)，性役割採用（sex role adoption：ある性 の顕在的な行動特性), 性役割発達 (sex role development：自分の性にふさわしい役割の習得・実現), 性役 割同一性 (sex role identity：自分自身の男性性・女性 性についての基碟的認知), 性役割志向性 (sex role orientation：性役割同一性と互換的な定義)，性役割選好 (sex role preference：男女どちらかの性に関連した行動 を採用したいとする願望/そのような行動を望ましいと する認知), 性役割態度 (sex role attitude：性役割に対 して一貫して好意的もしくは非好意的に反応する学習し た傾向）などの研究分野がある.これらの用語法や分類 法は今な打標準化されて抢らず，研究者によって巽なる 場合が要る。

性役割態度研究の意義としては以下のことが挙げられ る: (a) 態度は, 筆記用具で測定できる変数であり, 統計 的・比較文化的分析を使用した調查ができる; (b) 態度 は，個人をベースにした社会的 / 文化的変化を考察する ひとつのパースペクティブである (Berry, 1981). しか も, 性役割態度は, 教育・デート・結婚・育児・老人介 護・職業・平等・差別・女性解放運動・政治・法律・宗 教など人生のほとんどの段階・分野にも関連している. そこで，性役割態度を理解することは，性役割の変化の みでなく, 包括的な人々の意識変化・社会変化を理解す ることに導く；(c) 男女の性役割態度とさまざまな変数 との関係を理解すれば, 将来の態度や行動む推測でき る. 性役割態度は, そのような予測のためには最も重要 で示唆に富んだ研究分野と考えられる.

従来の性役割態度研究において, 心理学者㧍よび社会 学者は次のような点について研究を行っている：(a) 性 役割態度の変化; (b) 性役割態度と強い相関関係を有す る予測変数としての人口統計学的・サイコグラフィッ ク・社会経済的変数の発見および因果関係の検討; (c) 様々な変数 (e.g., 女性の就労, パーソナリティ特性, 男 性性・女性性, 同性愛, ストレス)を説明する要因とし ての性役割態度の検討などである.

\section{3 性役割態度測定法および尺度}

上記のような研究のために, 社会学に晾いては全国調 查・パネル調查・縱断的調查による態度变化の研究が行 われ，概して調查票の設問は少ないが調查でのサンプル 数が多いことが特徴である。心理学では，横断的調查が 多くサンプル数は比較的少ないが，態度の定量的な変化 を把握するために設問数の多い客観的な測定尺度が作 成・使用されている.

1970 年代には, 女性に関する多様な問題に対する態度 を測定する尺度が多数発表された. 女性の生活のあらゅ る面に打いて伝統的な性役割への志向性や男女平等観な どを測定するための一次元尺度が作成された. 対象者は 主に 16 歳以上の男女である. Beere はこれらの測定尺 度を検討し，作成段階，信頼性，妥当性について十分な 説明のある41の尺度を選択した（e.g.，Arnott，1972； Dempewolff, 1974 ; Beere, 1979). その中で最も古典的 なものは, belief pattern scale for measuring attitudes toward feminism (Kirkpatrick, 1936) である. 同尺度 は主に既婚女性の権利に対する態度を測定するもので， 現在も態度測定尺度の基本的なモデルとなっている。 また，これらの測定尺度の中で最むよく使用されている のは, the attitudes toward women scale (AWS) (Spence \& Helmreich, 1972; Spence, Helmreich, \& Stapp, 1973) で, AWS は現代アメリカ社会に打ける女 性の権利, 役割, 義務, 特権に対する態度から男女平等 意識の強さを測定する尺度である. Beere は，1970年 代に作成された女性に関する問題に対する態度測定尺度 一般のメソドロジー上の問題として，(a) 用語法が標準 化されていない；（b) 測定尺度の信頼性・妥当性が報告 されていない；(c) 測定される範囲が定義されていない などの久点を指摘した (Beere, 1979). 1980 年代になる と，女性の役割や問題に対する態度測定尺度 (Dreyer, Woods, \& James, 1981; Robinson \& Follingstad, 1985) ばかりでなく, 男女の役割や問題に対する態度測定尺度 が作成された. 例えば, the bias in attitudes survey (BIAS) (Jean \& Reynolds, 1980), the sex role egalitarianism scale (SRES) (Beere, King, Beere, \& King, 1984), the traditional egalitarian sex role scale (TESR) (Larsen \& Long, 1988) などである.この他, 男性の役割に対する態度測定尺度 (e.g., Fiebert, 1983； Thompson, Jr., Grisanti, \& Pleck, 1985) も作成されて いるが,この種の尺度は少ない。

\section{4 日本における性役割態度研究}

日本にお抒性役割態度の研究は, 1970 年代以来今日 まで続く総理府 (e.g., 1973) および日本放送協会 (NHK) (e.g., 1985) による日本人の意識変化の縱断的調查から 
始まった. 1980 年代以降には, 性役割態度と女性の職業 生活との結びつき (e.g., 平野・神田・小林, 1980), 性役 割意識の変化 (e.g., 木村, 1984; 見田, 1985), 性役割意 識の現状と分析 (e.g., 神田, 1982; 中野区, 1980 ; 鈴木, 1987), 比較文化調查（総理府, 1984; Sugiyama, 1984; 鈴木, 1991; Suzuki，1991）に関する報告などがされて いるが，文献は多くない。

従来の日本の調查では態度測定尺度が使用されないこ とが多く，使用される場合はアメリカの尺度の翻訳が利 用されてきた (東・小倉, 1984 ; 東, 1990). しかし, 日 本人の性役割態度の客観的測定尺度として, 平等主義的 性役割態度スケール (the scale of egalitarian sex role attitudes: SESRA) が作成された (Suzuki, 1989; 鈴木, 1991; Suzuki，1991). 同スケールは, 成年男女が結婚, 教育, 職業, 社会の4つのカテゴリーにおける性役割に 対する態度においてどの程度平等主義的か，あるいは伝 統主義的かを客観的に測定することを意図している.こ の他にも日本人 (青年)の性役割態度あるいは性役割観を 測定するための試みがなされつつある（石田, 1989; 佐 野, 1989).

\section{5 性役割態度の変化}

性役割態度を測定・分析した 1970 年代以降の心理学・ 社会学の文献をまとめ, 日本および最も研究の盛んなア メリカにおいて性役割態度がいかに変化してきてかを概 観する.

\section{日本での動向}

調查結果によると，日本人，特に女性の性役割態度が 1970 年代から 1988 年にかけて平等主義的方向へ変化し たことを示している.

（1）男女の役割に対する態度: 総理府広報室は, 1972 年以来, 女性に関する意識調査もしくは世論調査を 断続的に行っている (e.g., 総理府, 1973, 1988). 毎回 使われる設問のひとつが性による役割分業の肯定を端的 に表す “男は仕事, 女は家庭”である. 1972 年から 1987 年の閒には，設間に賛成のパーセンテージが $80 \%$ 強から $43 \%$ に減少し，日本人の性役割態度が以前より 平等主義的になったのは明らかである.この設問の回答 者の約 3 分の 1 は “どちらともいえない”を選んだ. 彼 らは完全な性による役割分業には賛成しないが，家庭や 職場での平等な役割分担を認めているわけでもない，基 本的には性役割態度は伝統主義的であるが，相手の役割 分担を自分の二次的・副次的な仕事とみなす柔軟さと現 実性を持ち合せている(神田，1982).

以下は NHK による日本人の意識の 4 回 $(1973,1978$, 1983，1988) にわたる縦断的調查の結果である (e.g., 秋 山, 1990).

（2）理想的な家庭に対する態度：1988 年の夫唱婦
随型 (20\%) と夫婦自立型 (18\%) のパーセンテージは, 1973 年とほとんど変りがないが，同期間に役割分担型 (25\%) は男女ともに著しく減少し，かわりに，家庭内協 力型 $(35 \%)$ が増加した. このタイプの性役割態度は, 総 理府 (1988) の調查で“どららとも言えない”と答えた 人に近いと考えられる。基本的には伝統主義的態度で, 相手の役割分担を助けているが，役割を性によってはっ きり分けて認識している. 家庭内協力型は, 役割分担型 の延長線上にあるやや平等主義的な傾向のあるタイプと 考えられる.

（3）既婚女性の就労に対する態度：調査では毎回, 男女回答者の約 40\% が育児優先型 (子供ができたら仕事 をやめる) に賛成しているが，家庭専念型は 15 年閒に $35 \%$ から $24 \%$ に減少し, 両立型は $20 \%$ から $33 \%$ に増 加した (e.g., 秋山, 1990). 女性では育児優先型も家庭専 念型も減少し続けて両立型のみが増加しているにもかか わらず, 男性は両立型が増加しても, 育児優先型が常に 約 40\% を維持している(秋山，1990).

（4）夫の家事に対する態度：過去 4 回の NHK 調 査の設問に対する回答中，1973 年から 1983 年の女性の 態度に最も大きな変化があった (17\% 増加) のは“夫が 台所の手伝いや子供の押もりをするのは当然だ”で, 男 女合わせると 1973 年から 1988 年に賛成が 19\% 増加し て約 70\% に達した. この変化は，性・年齢・教育レベ ル・職業に関係なく起ったが，設問の内容は夫が妻を手 伝うことで，平等に家事を分担することではない。

以上の結果から，日本人の性役割態度は，1970年以 来, 特に 1978 年以後男女ともに平等主義的な方向に変 化し, 男女の役割の区別が薄れてきていることが明らか になった. しかし, 全般的には, 夫が収入を得, 妻が暖 かい家庭を築くことに主たる責任を担うといら性別役割 分担の考え方が強い. 伝統主義的な態度の持主が減少し ても，平等主義的な態度の人より，擬似平等主義的一 表面上やや平等主義的だが基本的には伝統主義的一一態 度の人の方が増加しているのが今日の日本人の性役割態 度の特徵である.これは, 日本人の性役割態度が伝統主 義から平等主義への過渡期にあるからとも考えられる.

\section{アメリカでの動向}

アメリカ人男女の性役割態度が 1960 年代から 1985 年 にかけて, 特に 1970 年代に平等主義的な方向に変化し たことと，それが特定の層にのみ起きた変化ではなく， あらゆる人口統計学的グループに生じた共通の変化だと いうことが多数の研究報告書によって明らかにされた。

公民権法の制定と女性解放運動をはさむ 1964 年から 1974 年にかけて, 成人女性を対象にした性役割態度の調 査が 3 回行なわれた (Mason, Arber, \& Czajka, 1976). 分析によると, 各測定ごとに女性の性役割態度が平等主 義的な方向に変化し, 変化はあらゆる教育レベル・人口 
統計学的・社会経済的グループに，ほぼ同じ程度に起こ った. 既婚女性を対象にした 1962 年と 1977 年のパネル 調查でも, 男女の性役割態度が平等主義の方向にかなり 変化したが，変化は家事の分担などの具体的な面より， 原則論で大きいことが指摘された (Thornton \& Freedman, 1979). 女子大学生を対象にした調查では, 1969年 と 1973 年の間に，特に職業，収大，家庭での男女の役 割分担に扔いてフェミニスト的な考方方への大きな変化 が認められた (Parelius, 1975).

1970 年の全国調查による女性の性役割態度研究では 以下について強いコンセンサスが発見された：(a) 伝統 的に男女に期待される社会的責任；(b) 母親の就労が就 学以前の子供に与える影響; (c) 男女平等賃金と機会の 平等 (Mason \& Bumpass, 1975). Mason と Bumpass は，多くの女性が家庭での性による役割分担に対しては 伝統主義的でありながら女性の労働市場での権利にはリ ベラルなことから, 性役割態度のイデオロギーは一次元 ではないと結論づけた。

1970 年代に大って社会的, 政治的に保守的な傾向が強 くなったにもかかわらず, 18 歳以上の男女の社会調查か ら，男女の性役割態度が 1972 年より 1978 年の方が平等 主義的になり，変化の大部分は 1975 年の間に起こった ことが示唆された (Cherlin \& Walters, 1981). 1970 年 代半ばから 1980 年にかけての女性㧍よびその子供の性 役割態度の変化についてのパネル調查では，平等主義的 性役割態度への変化が一貫して続いていたことが明らか にされた (Thornton, Alwin, \& Camburn, 1983). さら に，3つのコホートの 1975 年から 1980 年にかけての縦 断的比較データから, 家庭内の性役割についての女性の 態度が一貫して平等主義的傾向にあることが確認された (McBroom, 1987).

1972 年から 1980 年にかけての大学生 およびその両親 の態度変化についての調查結果では両者に平等主義への 有意で大きな変化があったが，女子大学生は，1976 年か ら 1980 年にかけて，わずかだが有意に保守化の方向一 の変化を見せたことが判明した (Helmreich, Spence, \& Gibson, 1982). 著者らは, この保守化への変化が, 当 時の大学生の特徴とされた保守主義と一致すると解釈し た.しかし，フェミニズムに対するバックラッシュがあ ったとされている 1977 年から 1985 年にかけての女性の 家庭役割汶対する態度の全国調査の結果は, フェミニ ス卜的意見が男女ともに増加したことを明らかにした (Mason \& Lu, 1988). また, あらゆる人口統計学的・ 社会経済的グループにフェミニスト的傾向が浸透し, 各 コホートごとの段階的な変化より, コホート内での変化 の方が大きいことを示した。

\section{6 性役割態度と人口統計学的・社会経済的 特性との関係}

性役割態度と人口統計学的・社会経済的変数との関係 を記述し,どの変数が, 個人の性役割態度の重要な予測変 数になりらるかを明らかにする. 変数は, (a) 性, (b) 教 育, (c) 職業, (d) 年齢である. (この他に収入・子供の有 無・婚姻状況・宗教・人種などの調查結果もあるが, 数 が少なくて結果が一致しない傾向があり，性役割態度と の関係も強くないことが示唆されているので省略する.)

（1）性：男女の態度変化の調查では, ぞの国でも男 性の方が女性より伝統主義的である（e.g., 秋山、1990； 東・小倉, 1984 ; 東, 1990 ; Haworth, Povey, \& Clift, 1986; Jean \& Reynolds, 1980; 木村, 1984; Martin, Osmond, Hesselbart, \& Wood, 1980; Mason \& Lu, 1988; Nelson, 1988; Osmond \& Martin, 1975 ; Rao \& Rao, 1985; Tomeh, 1981; Tomeh \& Gallant, 1984). 性は性役割態度を予測する最む大切な変数である. 日本 では女性の平等主義的意識変化が男性に先行し, 男性の 変化はそれに従う(児鳥，1985)ことから，日本の男性が 将来いっそう平等主義的になることが予測される.

（2）教育レベル：教育レベルと性役割態度との関係 を調べたすべての研究者が強い相関関係を報告している ことから, 教育レベルは性役割態度の予測変数として最 も大切なもののひとつである.教育レベルが高いほど態 度が平等主義的である (e.g., Mason, Arber, \& Czajka, 1976; Mason \& Lu, 1988; NHK, 1985; Rosenberg, 1984 ; 鈴木, 1987; Suzuki, 1991; Tallichet \& Willits, 1986; Thornton \& Freedman, 1979). 教育レベルの高 以人の態度が平等主義的であるのは, 教育のおかげなの か，本来平等主義的な人がより高い教育を受けるのか, この因果関係について唯一の調查が Thornton らによ って行なわれた (Thornton et al., 1983). その結果判明 したことは, 教育レベルは性役割態度の形成に影響を与 えるが, 態度法教育レベルに影響を与えないということ である.

（3）職業：男性はほとんどの文化に抒いて働くこと が当然とみなされているが，女性にとってはライフスタ イル選択肢のひとつとしての要素が強い。そこで，性役 割態度と職業の有無・職種・雇用形態との関係が職業行 動の予測に重要になってくる。文献は, 職業が性役割態 度と最も一貫性のある関係をもつ予測变数のひとつであ ることを示している。すなおち, 有職・專門職・就労期 間が長い・働いた経験のある女性が，それぞれ無職・非 専門職・就労期間が短い・働いた経験のない女性より性 役割態度にお㤝る伀統性が低い (e.g., Mason et al., 1976; McBroom, 1987; Morgan \& Walker, 1983; Tallichet \& Willits, 1986; Thornton \& Freedman, 
1979).

日本では, 有職女性は無職の女性より平等主義的とい う報告(上子, 1979; 小木管, 1983) と, 職業の有無は性 役割態度と無関係といら報告（鈴木，1987）がある。一 方, 平等・自立志向の女性法うでない女性より仕事継 続を理想とする人が多く (東・目黒・神尾, 1990), 重回 鹵分析の結果からは, 専門的/管理的職業が平等主義的 性役割態度と強い相関関係があり, 非專門的/非管理的 職業および無職と性役割態度は無関係なことが明らかに された (Suzuki, 1989).つまり, 日本女性の性役割態度 予測変数としては職の有無より職種やキャリア志向が有 効なことが示唆されている.

職慈と性役割態度の因果関係の存在とその方向はあま り明らかにされていない，文献も少ないので一般化はで きないが, 結婚前ではなく結婚後の就学経験が母親の性 役割態度を決定する変数であり (Thornton et al., 1983), 雇用は性役割態度に弱い影響を与えるが, 逆方向の影響 はない (Bielby \& Bielby, 1984; Molm, 1978).

（4）年齢：年齢が平等主義的性役割態度と負の相関 関係にある予測変数だという報告がいくつかある (e.g., Morgan \& Walker, 1983; Nelson, 1988; Suzuki, 1989; Thornton, Alwin, \& Camburn, 1983). NHK 調査の結 果からも, 20 代後半の男女は態度が特に平等主義的にな ったことが指摘され (見田, 1985), 若い女性がより平等 主義的な態度を持つことも示唆されている (Bankart, 1985 ; 神田, 1982; 木村, 1984). 女性の世代別性役割 態度調査では, 祖母, 母親, 娘の順に保守的であった (Dambrot, Papp, \& Whitmore, 1984 ; Slevin \& Wingrove, 1983; Thornton et al., 1983). 若い方が, 平等主 義的な社会的䨌囲気のなかで䏍ち, 教育を受け, 社会の 風潮に敏感であるから, 態度が平等主義的になると考え られる。

以上の結果から, 高学歴, 管理職 / 専門職の若い女性 が平等主義的態度を持っ可能性が最も高いことが判明し た. Morgan と Walker は, 特にこのような特性を持つ 女性の態度が平等主義な方向へと変化するのは, 伝統主 義的であるより有利だからであることを交換理論を用い て説明している (Morgan \& Walker, 1983).

\section{7 性役割態度における比較文化研究}

比較文化的なパースベクティブは，それぞれの社会の 性役割態度に扝ける普遍性と独自性の理解に久かせな い. 国によってどのように違い，なぜ異なるのかを示せ ると同時に，共通性を見いだして一般原則をたてること もできる. しかし, 1980 年代に入って比較文化研究が増 加しつつあるものの, 絶対数が少なく, アフリカ, アジ ア, ラテンアメリカにおける研究は行われない傾向があ る (Rao \& Rao, 1985). また，わずかの例外を除いて (e.g., Parry, 1983；鈴木，1987；鈴木，1991：Suzuki; 1991)，要る国の人々を対象に作成した測定尺度を異文 化で使用する際に信頼性・妥当性の再検討を意りがち で, しかむ，いくつかの例外 (e.g., Joesting, 1982; Rosenberg, 1984) 以外, 研究の対象者が大学生に偏りがち である.

日本人の比較研究は少なく，女性の役割に対する態度 研究が主である。日本女性は他の国の女性に較べて全般 的に伝統主義的で (e.g., Campbell \& Brody, 1985; 総理 府, 1984; Sugiyama, 1984; Suzuki, 1991), 特に家事や 育児の男女分業を肯定するが，職業・社会に関しては平 等主義的な考え方を持つ (Campbell \& Brody，1985； Suzuki, 1991).

\section{8 性役割態度研究の問題点および今後望まれる研究}

(1) 調査対象者: 性役割態度研究の対象者はもっぱ ら女性に偏っている. 男女の役割が補完的で相互に依存 しあうことを考えれば，今後は男性の性役割態度研究が 増加することが望ましい，また，比較文化的パースペク ティブが久けていることから, 白人中産階級の学生や女

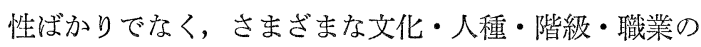
男女の調查を行なって, 普遍性を発見することが期待さ れる。

（2）調查方法: 使用されている態度測定尺度の信頼 性・妥当性の検討が行なわれなかったり, 質問項目が 1 つもしくは非常に少ない調查が多い。さらに, 縦断的調 查・パネル調查より, 横断的調查が主で, 態度と変数の 因果関係の検討や将来の行動予測が難しい. コホート分 析も少ない．これらを考慮した調查プランを計画するこ とが肝要である。

(3) 調查内容: 性役割態度研究ではあらゅる事柄に 対する態度の検討が求められているが，実際には家庭と 職業というコンテクストの中での態度研究が多い. 劇的 に変化する現代社会の具体的で客観的な姿を浮き彫りに し, 将来の態度予測を可能にするためには, 社会的・政 治的場面での性役割態度研究が今後一層必要になるであ ろう。また, 将来の行動予測のためには, 性役割態度変 化と行動変化の関係に関する研究も必要である。

\section{文献}

秋山登代 1990 シンポジウム“変わる日本人の意識” 調查研究報告資料 NHK 放送文化調査研究所

Andersen, M. L. 1988 Thinking about women. New York: Macmillan Publishing Company.

Arnott, C.C. 1972 Husbands' attitudes and wives' commitment to employment. Journal of Marriage and the Family, 34, 673-684.

東 清和 1990 青年期に扮ける性役割志向性の性差 社会心理学研究, 6, 97-106. 
東 清和 - 小倉千加子 1984 性役割の心理 大日本図 書

東 清和・目黑依子・神尾真知子 1990 女性の就労パ ターンに関する時系列的研究報告 東京都生活文化局

Bankart, B. B. 1985 Japanese attitudes toward women. Journal of Psychology, 119, 45-51.

Beere, C.A. 1979 Women and women's issues: $A$ handbook of tests and measures, San Francisco: Jossey-Bass Publishers.

Beere, C. A., King, D. W., Beere, D. B., \& King, L. A. 1984 The sex-role egalitarianism scale: A measure of attitudes toward equality between the sexes. Sex Roles, 10, 563-576.

Bem, S. L. 1974 The measurement of psychological androgyny. Journal of Consulting and Clinical Psychology, 42, 155-162.

Bem, S. L. 1976 Probing the promise of androgyny. In A. G. Kaplan \& J. P. Bean (Eds.), Beyond sexrole stereotypes: Readings toward a Psychology of androgyny. Boston: Little, Brown. Pp. 48-62.

Berry, J. W. 1981 Social and cultural change. In H. C. Triandis \& R. W. Brislin (Eds.), Handbook of cross-cultural psychology. Vol. 5. Social psychology. Boston: Allyn \& Bacon. Pp. 211-279.

Bielby, D.D.V., \& Bielby, W. T. 1984 Work commitment, sex-role attitudes, and women's employment. American Sociological Review, 49, 234-247.

Campbell, R., \& Brody, E. M. 1985 Women's changing roles and help to the elderly: Attitudes of women in the United States and Japan. Gerontologist, 25, 584-592.

Cherlin, A., \& Walters, P. B. 1981 Trends in United States men's and women's sex-role attitudes: 1972 to 1978. American Sociological Review, 46, 453-460.

Dambrot, F.H., Papp, M.E., \& Whitmore, C. 1984 The sex role attitudes of three generations of women. Personality and Social Psychology Bulletin, 10, 469-473.

Dempewolff, J.A. 1974 Development and validation of a feminism scale. Psychological Reports, 34, 651-657.

Dreyer, N. A., Woods, N.F., \& James, S.A. 1981 ISRO : A scale to measure sex-role orientation. Sex Roles, 7, 173-182.

Fiebert, M.S. 1983 Measuring traditional and liberated males' attitudes. Perceptual and Motor Skills, 56, 83-86.

Gerson, K. 1985 Hard choices. Berkeley : University of California Press.

Haworth, G., Povey, R., \& Clift, S. 1986 The attitudes towards women scale (AWS-B): A comparison of women in engineering and traditional occupations with male engineers. British Journal of Social Psychology, 25, 329-334.
Helmreich, R. L., Spence, J. T., \& Gibson, R. H. 1982 Sex-role attitudes: 1972-1980. Personality and Social Psychology Bulletin, 8, 656-663.

平野貴子・神田美知子・小林幸一郎・J.リドル 1980 女性の職業生活と性役割 社会学評論, 120，17-37.

石田英子 1989 フェミニズム度からみた性役割観の動 向 日本社会心理学会第 30 回大会発表論文集，151152.

Jean, P. J., \& Reynolds, C. R. 1980 Development of the bias in attitudes survey: A sex-role questionnaire. Journal of Psychology, 104, 269-277.

Joesting, J. 1982 Sex-role attitudes of Australian and United States women's rights activists. Psychological Reports, 51, 839-842.

上子武次 1979 家族役割の研究 ミネルヴァ書房

神田道子 1982 女たちのゆくえ 勁草書房

柏木惠子 1973 現代青年の性役割の習得 依田 新他 （編）現代青年心理学講座第 5 巻 金子書房 Pp. 101-139.

木村恵子 1984 女性の性役割意識 女性学研究会(編) 女たちのいま 勁草書房 Pp. 210-232.

Kirkpatrick, C. 1936 The construction of a beliefpattern scale for measuring attitudes toward feminism. Journal of Social Psychology, 7, 421-437.

児島和人 1985 意識変化の方向 - 過程 - 将来 NHK 世論調査部(編) 現代日本人の意識構造 日本放送出 版協会 P p. 183-213.

Larsen, K. S., \& Long, E. 1988 Attitudes toward sex-roles : Traditional or egalitarian? Sex Roles, 19, $1-12$.

Maccoby, E. E., \& Jacklin, C. 1974 The psychology of sex differences. Stanford; Stanford University Press.

間宮 武 1979 性差心理学 金子書房

Martin, P. Y., Osmond, M. W., Hesselbart, S., \& Wood, M. 1980 The significance of gender as a social and demographic correlate of sex role attitudes. Sociological Focus, 13, 383-396.

Mason, K. O., Arger, A., \& Czajka, J.L. 1976 Changes in U.S. women's sex-role attitudes, 19641974. American Sociological Review, 41, 573-596.

Mason, K. O., \& Bumpass, L. L. 1975 U.S. women's sex-role ideology, 1970. American Journal of Sociology, 80, 1212-1219.

Mason, K. O., \& Lu, Y. 1988 Attitudes toward women's familial roles: Changes in the United States, 1977-1985. Gender and Society, 2, 39-57.

McBroom, W.H. 1987 Longitudinal change in sex role orientations: Differences between men and women. Sex Roles, 16, 439-452.

見田宗介 1985 現代青年の意識の変貌 見谷宗介・山 本 泰・住藤健二(編) 文化と社会意識 東京大学出 版会 Pp. 76-94。

Molm, L. D. 1978 Sex role attitudes and the em- 
ployment of married women: The direction of causality. Sociological Quarterly, 19, 522-533.

Money, J., \& Ehrhardt, A. 1972 Man and woman, boy and girl. Baltimore: Johns Hopkins University Press.

Morgan, C.S., \& Walker, A. J. 1983 Predicting sex role attitudes. Social Psychology Quarterly, 46, 148-151.

中野区婦人問題担当 1980 中野区婦人問題実態調查

Nelson, M. C. 1988 Reliability, validity, and crosscultural comparisons for the simplified attitudes toward women scale. Sex Roles, 18, 289-296.

NHK 世論調查部(編) 1985 現代日本人の意識構造 日本放送出版協会

小木娄英一(監修)生命保險文化センター(編) 198380 年代 女性の生活 現在と将来 日本放送出版協会

Osmond, M. W., \& Martin, P. Y. 1975 Sex and sex ism: A comparison of male and female sex-role attitudes. Journal of Marriage and the Family, 37, 744-758.

Parelius, A.P. 1975 Emerging sex-role attitudes, expectations, and strains among college women. Journal of Marriage and the Family, 37, 146-153.

Parry, G. 1983 A British version of the attitudes towards women scale (AWS-B). British Journal of Social Psychology, 22, 261-263.

Rao, V.V.P., \& Rao, V.N. 1985 Sex-role attitudes across two cultures: United States and Inia. Sex Roles, 13, 607-624.

Robinson, E. A., \& Follingstad, D. R. 1985 Development and validation of a behavioral sex-role inventory. Sex Roles, 13, 691-707.

Rosenberg, T.J. 1984 Sex-role attitudes of working-class women in Bogota, Colombia, 1977. Sex Roles, 11, 79-91.

佐野幸子 1989 性別態度の測定について 日本社会心 理学会第 30 回大会論文集, 153-154.

Slevin, K. F., \& Wingrove, C. R. 1983 Similarities and differences among three generations of women in attitudes toward the female role in contemporary society. Sex Roles, 9, 609-624.

総理府婦人問題担当室 1984 婦人問題に関する国際比 較調查

総理府広報室 1973 婦人に関する意識調査

総理府広報室 1988 女性に関する世論調查

Spence, J.T, \& Helmreich, R. L. 1972 The attitudes toward women scale: An objective instru- ment to measure attitudes toward the rights and roles of women in contemporary society. Journal Supplement Abstract Service Catalog of selected Documents in Psychology, 2, 66.

Spence, J. T., Helmreich, R. L., \& Stapp, J. A. 1973 A short version of attitudes toward women scale (AWS). Bulletin of the Psychonomic Society, 2, 219 220 .

Sugiyama, M. 1984 A woman's place in society comparative attitudes in Japan, West Germany and the United States. Behaviometrika, 15, 55-75.

鈴木淳子 1987 フェミニズム・スケールの作成と信頼 性・妥当性の検討 社会心理学研究, 2, 45-54.

Suzuki, A. 1989 The scale of egalitarian sex role attitudes: scale development and comparison of American and Japanese women. Unpublished master's thesis, Harvard University, Cambridge, M. A. 鈴木淳子 1991 平等主義的性役割態度 : SESRA (英語 版）の信頼性と妥当性の検討及び日米女性の比較 社 会心理学研究, 6, 80-87.

Suzuki, A. 1991 Egalitarian sex role attitudes: Scale development and comparison of American and Japanese women. Sex Roles, 24, 245-259.

Tallichet, S. E., \& Willits, F. K. 1986 Gender-role attitude change of young women: Influential factors from a panel study. Social Psychology Quarterly, 49, 219-227.

Thompson, E. H., Jr., Grisanti, C., \& Pleck, J.H. 1985 Attitudes toward the male role and their correlates. Sex Roles, 13, 413-427.

Thornton, A., Alwin, D. F., \& Camburn, D. 1983 Causes and consequences of sex role attitudes and attitudes change. American Sociological Review, 48, 211-227.

Thornton, A., \& Freedman, D. 1979 Changes in the sex role attitudes of women, 1962-1977: Evidence from a panel study. American Sociological Review, 44, 831-842.

Tomeh, A. K. 1981 Correlates of sex role attitudes in a Korean student population. Journal of Asian and African studies, 16, 169-185.

Tomeh, A. K., \& Gallant, C. J. 1984 French men's and women's sex role attitudes. International Journal of Comparative Sociology, 25, 226-242.

- 1990.7.2. 受稿, 1991.1.19, 受理- 